\title{
Study and Suggestion on Industrial Energy Efficiency of 13th Five Year Plan
}

\author{
Ren Liu ${ }^{1, *}$, Xia Yujuan ${ }^{1}$, Sinan Zhang ${ }^{1}$, Zhonghang Wang ${ }^{1}$ \\ ${ }^{1}$ China National Institution of Standardization, Beijing, 100191, China
}

\begin{abstract}
The determination of energy consumption and conservation targets during the 13th Five-Year Plan lies in the core of the 13th Five-Year energy conservation planning. In this paper, the top-down decomposition methods was been employed to calculate China energy consumption, and research on the prediction of the development of industrial energy efficiency. In the end, author gave the suggestions to show the double control for energy consumption intensity and total consumption is the best way to fulfil the target of industrial energy efficiency of 13th five year plan energy consumption plan.
\end{abstract}

\section{INTRODUCTION}

As China's fast-growing economy transits into a "new normal" and with the strategically economic restructuring, the growth of energy consumption during the 13th Five-Year Plan will gradually slow down. The general energy consumption however will remain growing until 2020. The determination of energy consumption and conservation targets during the 13th Five-Year Plan lies in the core of the 13th Five-Year energy conservation planning. In this paper, top-down decomposition method was employed to calculate China energy consumption.

The Energy Development Strategy Action Plan (2014-2020) issued by the State Council in June 2014 has set the target of controlling the total primary energy consumption in 2020 at about 4.8 billion tce, according to which, if the 12th Five-Year energy conservation target can be realized as scheduled, the average annual rise of energy consumption will be 149 million tce in the 12th Five-Year Plan and may be relaxed to 157 million tce in the 13th Five-Year Plan. Therefore, it is a relatively relax target to control the total energy consumption at 4.8 billion tce. See figure1.

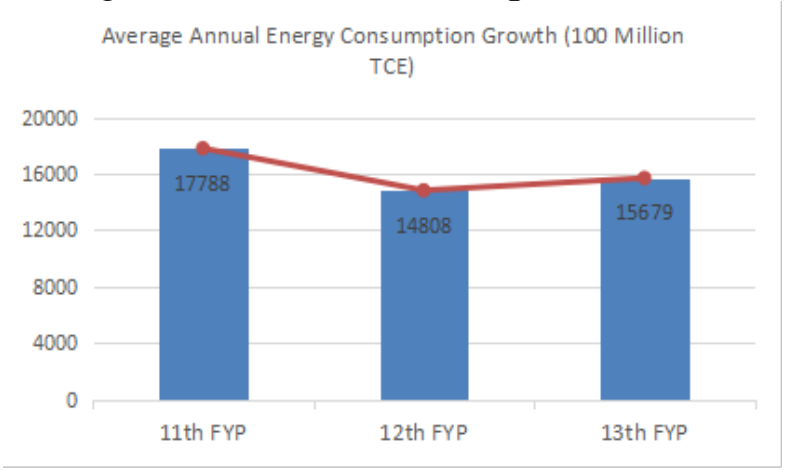

Fig. 1. Incremental Energy Consumption in the Last Three Five-Year Plans.
Based on the target set forth in the State Council document, the research group further decomposes the national energy consumption into three major energy consumption sectors, namely, industry, construction and transportation, and by combining the judgment on the future strategically economic restructuring as well as the change trend of the economic activity level and energy efficiency in these three sectors, predicts the energy consumption prospects in a top-down manner, see the table below.

Table 1. Top-Down Assumption of Energy Consumption Changes in Three Major Sectors.

\begin{tabular}{|r|c|c|c|}
\hline & 2010 & 2015 & 2020 \\
\hline $\begin{array}{r}\text { Total energy consumption } \\
\text { Agriculture, forestry, animal } \\
\text { husbandry and fishery }\end{array}$ & 6477 & 7142 & 7924 \\
\hline Industry & 232019 & 269749 & 294730 \\
\hline $\begin{array}{r}\text { Construction } \\
\text { post industry }\end{array}$ & 5309 & 6783 & 7638 \\
\hline $\begin{array}{r}\text { Wholesale, retailing, } \\
\text { accommodation and catering }\end{array}$ & 6827 & 13964 & 26256 \\
\hline Other & 13681 & 16757 & 21482 \\
\hline $\begin{array}{r}\text { Living consumption } \\
\text { rantion, warehousing and }\end{array}$ & 34558 & 46680 & 62058 \\
\hline
\end{tabular}

Through analysis, the research group found that the energy consumption allocated to the three end-use

\footnotetext{
* Corresponding author: liuren2001@aliyun.com
} 
energy consumption sectors (industry, construction and transportation) is relaxed for their productive and living activities. Therefore, the target of controlling the total energy consumption at 4.8 billion tce in 2020 can be further tightened by intensifying energy conservation.

\section{Prediction of Economic Activities and Energy Consumption of Industrial, Construction and Transportation Sectors in the 13th Five-Year Plan}

\subsection{Prediction of the development of key economic and social activities in key areas}

The rate of economic growth and the level of economic and social development activities in sectors such as industry, construction and transportation are the fundamental factors determining the level of future energy consumption demand. Considerable assumptions have been made by the research group in the course of study. For example, as shown in Table 2, the research group has assumed the development of key activities in the industrial sector.

Table 2. Output of Main Energy-Intensive Products at the End of the 13th Five-Year Plan.

\begin{tabular}{|c|c|c|c|c|}
\hline & Unit & 2010 & 2015 & 2020 \\
\hline $\begin{array}{c}\text { Paper and } \\
\text { paperboard }\end{array}$ & $10,000 \mathrm{t}$ & 10036 & 12190 & 14342 \\
\hline $\begin{array}{c}\text { Synthetic } \\
\text { ammonia }\end{array}$ & $10,000 \mathrm{t}$ & 4970 & 5500 & 5470 \\
\hline $\begin{array}{c}\text { Caustic } \\
\text { soda }\end{array}$ & $10,000 \mathrm{t}$ & 2087 & 2500 & 2800 \\
\hline $\begin{array}{c}\text { Sodium } \\
\text { carbonate }\end{array}$ & $10,000 \mathrm{t}$ & 2029 & 2400 & 2800 \\
\hline $\begin{array}{c}\text { Calcium } \\
\text { carbide }\end{array}$ & $10,000 \mathrm{t}$ & 1700 & 1950 & 2000 \\
\hline Ethylene & $10,000 \mathrm{t}$ & 1419 & 2900 & 5000 \\
\hline Cement & $100,000,000 \mathrm{t}$ & 18.8 & 25.6 & 28.7 \\
\hline $\begin{array}{c}\text { Sheet glass } \\
100,000,000 \mathrm{t} \\
\text { weight cases }\end{array}$ & 6.3 & 7.2 & 7.5 \\
\hline Crude steel & $100,000,000 \mathrm{t}$ & 6.27 & 7.32 & 7.9 \\
\hline $\begin{array}{c}\text { Aluminum } \\
\text { oxide }\end{array}$ & $10,000 \mathrm{t}$ & 2894 & 3971 & 4545 \\
\hline $\begin{array}{c}\text { Electrolytic } \\
\text { aluminum }\end{array}$ & $10,000 \mathrm{t}$ & 1565 & 2200 & 2600 \\
\hline Copper & $10,000 \mathrm{t}$ & 457 & 700 & 1200 \\
\hline
\end{tabular}

\subsection{Calculation results of energy consumption in key areas}

Based on the previous data, the research group calculated the energy consumption in industrial, construction and transportation sectors in 2020 by a bottom-up method, see table 3.

Table 3. Sectoral Structure of Energy Consumption in China in 2020 (Unit: 10,000 tce)

\begin{tabular}{|r|c|c|c|c|}
\hline & 2005 & 2010 & 2015 & 2020 \\
\hline $\begin{array}{r}\text { Total energy } \\
\text { consumption }\end{array}$ & 235997 & 324939 & 402793 & 465257 \\
\hline
\end{tabular}

\begin{tabular}{|r|c|c|c|c|}
\hline $\begin{array}{r}\text { Agriculture, forestry, } \\
\text { animal husbandry } \\
\text { and fishery }\end{array}$ & 6071 & 6477 & 7142 & 7924 \\
\hline Industry & 168724 & 232019 & 279409 & 311635 \\
\hline $\begin{array}{r}\text { Construction } \\
\text { Transportation, }\end{array}$ & 3403 & 5309 & 6458 & 7276 \\
\hline $\begin{array}{r}\text { warehousing and post } \\
\text { industry }\end{array}$ & 18391 & 26068 & 38610 & 52003 \\
\hline $\begin{array}{r}\text { Wholesale, retailing, } \\
\text { accommodation and } \\
\text { catering }\end{array}$ & 4848 & 6827 & 8778 & 10339 \\
\hline Other & 9255 & 13681 & 17591 & 20718 \\
\hline Living consumption & 25305 & 34558 & 44806 & 55362 \\
\hline Private car & 1363 & 2909 & 5019 & 7505 \\
\hline $\begin{array}{r}\text { Building energy } \\
\text { consumption in life }\end{array}$ & 23942 & 31649 & 39787 & 47857 \\
\hline
\end{tabular}

\subsection{Activity level and efficiency of energy consumption actions in industrial, construction and transportation sectors}

The research group, based on the systematic analysis and the expert analysis, assumed the indicators of key activity level and energy efficiency in industrial, construction and transportation sectors. Due to the limited space, only the prediction of energy efficiency improvement in the industrial sector by the research group is presented here (see table 4 and 5)

Table 4. Comprehensive Energy Consumption of Main Energy-Intensive Products at the End of the 13th Five-Year Plan

\begin{tabular}{|c|c|c|c|c|}
\hline Product & Unit & 2010 & 2015 & 2020 \\
\hline Crude steel & $\mathrm{kgce} / \mathrm{t}$ & 605 & 580 & 560 \\
\hline Cement & $\mathrm{kgce} / \mathrm{t}$ & 100 & 93 & 87 \\
\hline $\begin{array}{c}\text { Electrolytic } \\
\text { aluminum }\end{array}$ & $\mathrm{kWh} / \mathrm{t}$ & 13979 & 13300 & 13000 \\
\hline Sheet glass & $\begin{array}{c}\mathrm{kgce} / \mathrm{weight} \\
\text { case }\end{array}$ & 17 & 15 & 14 \\
\hline Ethylene & $\mathrm{kgce} / \mathrm{t}$ & 950 & 857 & 840 \\
\hline $\begin{array}{c}\text { Paper and } \\
\text { paperboard }\end{array}$ & $\mathrm{kgce} / \mathrm{t}$ & 380 & 330 & 300 \\
\hline $\begin{array}{c}\text { Calcium } \\
\text { carbide }\end{array}$ & $\mathrm{kgce} / \mathrm{t}$ & 1000 & 900 & 830 \\
\hline $\begin{array}{c}\text { Synthetic } \\
\text { ammonia }\end{array}$ & $\mathrm{kgce} / \mathrm{t}$ & 1402 & 1350 & 1300 \\
\hline
\end{tabular}

Table 5. Added-Value Energy Consumption in Major Non Energy-Intensive Industries at the End of the 13th Five-Year Plan Unit: tce / CNY 10,000 (2010 price)

\begin{tabular}{|c|c|c|c|}
\hline Industry & 2010 & 2015 & 2020 \\
\hline $\begin{array}{c}\text { Electronic } \\
\text { equipment } \\
\text { manufacturing }\end{array}$ & 0.297 & 0.255 & 0.214 \\
\hline $\begin{array}{c}\text { Transportation } \\
\text { equipment } \\
\text { manufacturing }\end{array}$ & 0.113 & 0.097 & 0.081 \\
\hline $\begin{array}{c}\text { Machine } \\
\text { manufacturing }\end{array}$ & 0.19 & 0.163 & 0.137 \\
\hline Metal product & 0.248 & 0.213 & 0.179 \\
\hline $\begin{array}{c}\text { Rubber and plastic } \\
\text { products }\end{array}$ & 0.386 & 0.332 & 0.278 \\
\hline Pharmaceuticals & 0.402 & 0.346 & 0.289 \\
\hline Culture and printing & 0.279 & 0.223 & 0.184
\end{tabular}




\begin{tabular}{|c|c|c|c|}
\hline Woodwork & 0.165 & 0.135 & 0.116 \\
\hline $\begin{array}{c}\text { Textile and chemical } \\
\text { fiber products } \\
\text { manufacturing }\end{array}$ & 0.262 & 0.197 & 0.157 \\
\hline $\begin{array}{c}\text { Food and tobacco } \\
\text { processing }\end{array}$ & 0.411 & 0.337 & 0.288 \\
\hline
\end{tabular}

\section{Main Approaches to the 13th Five- Year Energy Conservation Target}

On the basis of the above analysis, the research group calculated the main approaches to the 13th Five-Year energy conservation target. In general, these approaches can be divided into four categories, i.e., economic restructuring and industrial, building and transportation energy conservation.

\subsection{Firmly carry out strategic adjustment of the economy}

Calculation results show that about 182 million tce will be contributed for reduction target of energy consumption per unit GDP during the 13th Five-Year Plan due to the change of the three industrial structures. About 13.18 million tce will be contributed for the reduction target of energy consumption per unit GDP during the 13th Five-Year Plan by energy conservation of the internal structure of secondary industry (namely the savings caused by the change of proportions of the industry and the building industry). About 13.18 million tce will be contributed for the reduction target of energy consumption per unit GDP during the 13th Five-Year Plan by energy conservation of the internal structure of tertiary industry (namely the savings caused by the change of proportions of the transportation industry and service industries in addition to transportation). The total contributed savings is about 211 million tce, accounting for $29.4 \%$ of the total energy conservation task (716 million tce).

\subsection{Strengthen energy conservation of the industrial sector}

Calculation results show that 246.84 million tce will be contributed for the reduction target of energy consumption per unit GDP during the 13th Five-Year Plan by the structural adjustment inside the industry. 139.79 million tce may be saved due to technological progress in energy conservation, technological improvement, scale production and backward production capacity elimination in the energy-exhaustive industries, and product structure adjustment inside various industries. 59.62 million tce may be saved by technological progress of non-energy-exhaustive industries and structural adjustment inside various industries. The three industries contributed the total energy savings of 446.25 million tce, accounting for $62.3 \%$ of the total energy conservation task.

\section{Control target for incremental energy consumption of all regions during the 13th Five-Year Plan}

For the purpose of promoting energy resource conservation and utilization, the target of the energy conservation plan during "the 13th Five-Year Plan" will be transformed from single energy conservation target to the "double control" for energy intensity and total energy consumption. The control targets for intensity and total consumption shall be coordinated and complementary. These two targets shall be consistent based on the consistent expectations for GDP. For this, the total consumption target can be derived from energy intensity targets of all regions, which is a way to obtain the total energy of various regions. Besides, the energy consumption elasticity coefficient of one region is kept stable essentially over a period of time. The regional total energy consumption distribution plan can be obtained by the elasticity coefficient method. Due to a certain difference between the national and regional total statistical data in China, regional decomposition for incremental energy consumption is more direct and definite plan.

Table 6. energy Increment Control Targets of All Regions during the 13th Five-Year Plan by Two Methods

\begin{tabular}{|c|c|c|c|}
\hline Regions & $\begin{array}{l}\text { Increment by } \\
\text { the intensity } \\
\text { target }(10,000 \\
\text { tce })\end{array}$ & $\begin{array}{l}\text { Increment by } \\
\text { the elasticity } \\
\text { coefficient } \\
(10,000 \text { tce })\end{array}$ & $\begin{array}{c}\text { Difference } \\
\text { between the } \\
\text { two } \\
\text { schemes* }\end{array}$ \\
\hline Beijing & 564 & 512 & $9.7 \%$ \\
\hline Tianjin & 2242 & 2234 & $0.4 \%$ \\
\hline Hebei & 2409 & 3323 & $31.9 \%$ \\
\hline Shanxi & 2414 & 2499 & $3.4 \%$ \\
\hline $\begin{array}{c}\text { Inner } \\
\text { Mongolia }\end{array}$ & 3517 & 3711 & $5.4 \%$ \\
\hline Liaoning & 3185 & 3535 & $10.4 \%$ \\
\hline Jilin & 1484 & 1410 & $5.1 \%$ \\
\hline Heilongjiang & 1200 & 1485 & $21.2 \%$ \\
\hline Shanghai & 856 & 1042 & $19.6 \%$ \\
\hline Jiangsu & 4765 & 5036 & $5.5 \%$ \\
\hline Zhejiang & 1963 & 2190 & $10.9 \%$ \\
\hline Anhui & 2550 & 2448 & $4.1 \%$ \\
\hline Fujian & 2460 & 2595 & $5.3 \%$ \\
\hline Jiangxi & 1530 & 1463 & $4.5 \%$ \\
\hline Shandong & 6173 & 6147 & $0.4 \%$ \\
\hline Henan & 4173 & 3937 & $5.8 \%$ \\
\hline Hubei & 3854 & 3616 & $6.4 \%$ \\
\hline Hunan & 3484 & 3182 & $9.1 \%$ \\
\hline Guangdong & 3261 & 4230 & $25.9 \%$ \\
\hline Guangxi & 1766 & 2109 & $17.7 \%$ \\
\hline Hainan & 381 & 458 & $18.3 \%$ \\
\hline Chongqing & 2733 & 2416 & $12.3 \%$ \\
\hline Sichuan & 4380 & 3916 & $11.2 \%$ \\
\hline Guizhou & 3092 & 2716 & $13.0 \%$ \\
\hline Yunnan & 2484 & 2554 & $2.8 \%$ \\
\hline Tibet & - & - & - \\
\hline Shaanxi & 2621 & 2646 & $0.9 \%$ \\
\hline Gansu & 1500 & 1360 & $9.8 \%$ \\
\hline Qinghai & 1115 & 1297 & $15.1 \%$ \\
\hline Ningxia & 813 & 958 & $16.3 \%$ \\
\hline Xinjiang & 3896 & 7019 & $57.2 \%$ \\
\hline
\end{tabular}




\begin{tabular}{|c|c|c|c|}
\hline Regions & $\begin{array}{c}\text { Increment by } \\
\text { the intensity } \\
\text { target }(10,000 \\
\text { tce })\end{array}$ & $\begin{array}{c}\text { Increment by } \\
\text { the elasticity } \\
\text { coefficient } \\
(10,000 \text { tce })\end{array}$ & $\begin{array}{c}\text { Difference } \\
\text { between the } \\
\text { two } \\
\text { schemes* }\end{array}$ \\
\hline $\begin{array}{c}\text { Regional } \\
\text { total }\end{array}$ & 76868 & 82045 & $6.5 \%$ \\
\hline
\end{tabular}

* The difference between the two plans is defined as $\frac{2|c-d|}{c+d}$, c represents the increment by the intensity target, and $d$ represents the increment by the elasticity coefficient.

\section{Suggestions for the Energy Conservation Target}

Based on the aforesaid research, the research group proposes the following suggestions to ensure the energy conservation target during "the 13th Five-Year Plan":

\subsection{Intensify "double control" for energy consumption intensity and total consumption}

It is suggested that the central government should emphasize importance of the ecological civilization construction, promote energy conservation and emission reduction unswervingly, strive to find out a new way to lower energy emission and improve economic development, and make unremitting efforts to promote energy consumption revolution firmly. The decline rate of energy consumption per unit GDP of "the 13th FiveYear Plan" will be determined to be about $15 \%$, and the total energy consumption control target is set as 4.8 billion tce. The above two indexes will be incorporated into the national economy and social development planning outline of "the 13th Five-Year Plan". The total energy consumption targets of industry, building and transportation sectors are respectively 3,100 million, 800 million and 600 million tce as the anticipatory indexes. The targets of unit activity level (product, unit area or unit turnover) of the industry, building and transportation are incorporated into the relating national energy conservation planning as the anticipatory indexes.

\subsection{Carry out industrial structure adjustment firmly}

It is suggested to focus on "boosting growth" during "the 13th Five-Year Plan", optimize and adjust the economy based on its development rule by virtue of properly lowering the economic growth speed, and exert the market force more greatly with the aid of deepening the form, so as to reduce the excessive intervention to the economic growth from the governmental "visible hand". We strive to improve the proportion of the third industry by $5 \%$ during "the 13th Five-Year Plan" based on the strategic adjustment for the economic structure.

\subsection{Boost the industrial energy conservation to improve quality and efficiency}

It is necessary to speed up the development of such advanced technologies as informatization, network technology and cloud computing, actively cultivate such strategic emerging industry as energy conservation and environmental protection, and promote the internal structure adjustment of the industry. Haphazard development of steel, cement and building materials shall be strictly limited. The central government shall strengthen early warning and monitoring for new energy-exhaustive and high-pollution projects, set more severe energy conservation and environmental protection access threshold, and take the approval policy of "decremental substitution". There is a necessary to control the industrial sector development speed, and strive to achieve peak production of steel, cement and other basic raw material industries by 2020 . The energy efficiency levels of main energy-exhaustive products will reach the leading level of the world in 2020 by virtue of transforming the industrial energy conservation technology, eliminating the out-dated energy production line and energy-exhaustive equipment, and boosting transform of such universal equipment as industrial boiler and electric motor driving system.

\section{References}

1. N. Wang, Y. Zhu, T. Yang. The impact of transportation infrastructure and industrial agglomeration on energy efficiency: Evidence from China's industrial sectors[J]. Journal of Cleaner Production,2020,244.

2. Miguel A. Bermeo, Carlos Ocampo-Martinez. Energy efficiency improvement through MPC-based peripherals management for an industrial process test-bench[J]. IFAC PapersOnLine,2019,52(13).

3. W. König. Energy efficiency in industrial organizations----A cultural-institutional framework of decision making[J]. Energy Research \&amp; Social Science, 2020, 60.

4. $\mathrm{Yu}$ Binbin. Industrial structure, technological innovation, and total-factor energy efficiency in China. [J]. Environmental science and pollution research international, 2020.

5. Engineering - Industrial Engineering; Findings in Industrial Engineering Reported from National Taiwan University of Science and Technology (Resolving conflict objectives between environment impact and energy efficiency - An optimization modeling on multiple-energy deployment) [J]. Energy Weekly News, 2020.

6. Tone K.Variations on the Theme of Slacks-based Measure of Efficiency in DEA[J].European Journal of Operational research, 1995, 200(3): 901-907. 